\title{
Article
}

\section{PD-L1 Is an Independent Prognostic Marker in Middle Eastern PTC and Its Expression Is Upregulated by BRAFV600E Mutation}

\author{
Abdul K. Siraj ${ }^{1,+}$, Sandeep Kumar Parvathareddy ${ }^{1,+}{ }^{\dagger}$ Poyil Pratheeshkumar ${ }^{1}$, Sasidharan Padmaja Divya ${ }^{1}$, \\ Saif S. Al-Sobhi ${ }^{2}$, Fouad Al-Dayel ${ }^{3}$ and Khawla S. Al-Kuraya ${ }^{1, *(1)}$ \\ 1 Human Cancer Genomic Research, Research Center, King Faisal Specialist Hospital and Research Center, \\ P.O. Box 3354, Riyadh 11211, Saudi Arabia; asiraj@kfshrc.edu.sa (A.K.S.); \\ psandeepkumar@kfshrc.edu.sa (S.K.P.); ppoyil@kfshrc.edu.sa (P.P.); pdivya@kfshrc.edu.sa (S.P.D.) \\ 2 Department of Surgery, King Faisal Specialist Hospital and Research Center, P.O. Box 3354, Riyadh 11211, \\ Saudi Arabia; sobhi@kfshrc.edu.sa \\ 3 Department of Pathology, King Faisal Specialist Hospital and Research Centre, P.O. Box 3354, Riyadh 11211, \\ Saudi Arabia; dayelf@kfshrc.edu.sa \\ * Correspondence: kkuraya@kfshrc.edu.sa; Tel.: +966-11-205-5167 \\ + These authors contributed equally to this work.
}

check for updates

Citation: Siraj, A.K.; Parvathareddy, S.K.; Pratheeshkumar, P.; Divya, S.P.; Al-Sobhi, S.S.; Al-Dayel, F.; Al-Kuraya, K.S. PD-L1 Is an Independent Prognostic Marker in Middle Eastern PTC and Its Expression Is Upregulated by BRAFV600E Mutation. Cancers 2021, 13, 555. https://doi.org/10.3390/ cancers13030555

Academic Editors: Antonio Curti, Alessandro Isidori, Giuseppe Lo Russo and Marina Chiara Garassino

Received: 28 December 2020

Accepted: 27 January 2021

Published: 1 February 2021

Publisher's Note: MDPI stays neutral with regard to jurisdictional claims in published maps and institutional affiliations.

Copyright: (c) 2021 by the authors. Licensee MDPI, Basel, Switzerland. This article is an open access article distributed under the terms and conditions of the Creative Commons Attribution (CC BY) license (https:// creativecommons.org/licenses/by/ $4.0 /)$.
Simple Summary: This study was conducted to investigate the prognostic significance of programmed death-ligand 1 (PD-L1) expression in a large cohort of Middle Eastern papillary thyroid carcinoma (PTC) patients and to explore the correlation of PD-L1 and BRAFV600E mutations in PTC tumors and cell lines. We found PD-L1 over-expression in PTC patients and it was significantly associated with aggressive clinico-pathological parameters and $B R A F$ mutation. PTC patients with co-existing PD-L1 over-expression and $B R A F$ mutation had a poor disease-free survival. In vitro studies showed that BRAF inhibition induces PD-L1 expression in BRAF-mutated PTC cell lines via mitogen-activated protein kinase kinase/extracellular-signal-regulated kinase (MEK/ERK) pathway activation. Silencing of PD-L1 in BRAF-mutated cell lines significantly attenuated cell growth. Our data suggest that PD-L1 could represent a useful prognostic marker for risk stratification in Middle Eastern PTC and that a programmed cell death protein 1 (PD-1)/PD-L1 inhibitor could be a potential therapeutic option for aggressive PTC cancers, such as the tall cell variant, $B R A F$ mutation-positive patients that are unresponsive to standard PTC treatment.

Abstract: PD-L1 inhibition is a promising therapeutic target whose efficacy has been demonstrated in several cancers. Immunohistochemistry was performed to assess PD-L1 protein expression in PTC. We further conducted in vitro analysis to investigate the role of PD-L1 in regulating BRAFV600E in PTC cell lines. PD-L1 over-expression was noted in 32.4\% (473/1458) of cases and significantly associated with aggressive clinico-pathological parameters. Importantly, PD-L1 was found to be an independent poorer prognostic marker. We also found PD-L1 to be significantly associated with $B R A F$ mutation and patients with co-existing PD-L1 over-expression and BRAF mutation had a poor disease-free survival compared to patients with $B R A F$ mutation alone. In vitro analysis showed high expression of PD-L1 in BRAF-mutated PTC cell lines compared to a $B R A F$ wild-type cell line. Inhibition of BRAF using vemurafenib induced PD-L1 expression in BRAF-mutated cell lines without affecting cell growth. Knockdown of PD-L1 in BRAF-mutated cell lines significantly decreased the cell growth and induced apoptosis. Our data suggest that PD-L1 might represent a useful prognostic marker in Middle Eastern PTC and PD-L1 inhibition could be a potential therapeutic option for aggressive PTC cancers, such as the tall cell variant, $B R A F$ mutation-positive patients that are unresponsive to standard treatment.

Keywords: PD-L1; BRAFV600E mutation; papillary thyroid cancer; recurrence-free survival; cell growth; vemurafenib 


\section{Introduction}

Papillary thyroid carcinoma (PTC) is the commonest among all thyroid carcinomas [1,2]. Although PTCs are indolent, successfully curable and have an overall good prognosis, however, $20 \%$ of PTCs show recurrence and about $5 \%$ manifest with distant metastasis and may become resistant to radioactive iodine therapy [3-5]. Therefore, identifying new molecular targets that could predict prognosis is essential to overcome adverse outcomes in PTC patients.

Recently, one of the potential targets that has been under close scrutiny is programmed cell death ligand 1 (PD-L1) [6,7]. PD-L1 is a key immune regulatory molecule that interacts with programmed cell death protein (PD-1) to suppress $\mathrm{T}$ cell immune responses that help the tumor cells to escape the immune system $[8,9]$. Blockade of the PD-1/PD-L1 pathway with monoclonal antibodies is a promising therapeutic strategy that shows strong clinical benefits in multiple malignancies [10-13]. Despite PD-L1 protein expression being used as a predictive marker of therapeutic response to PD-L1 inhibitors in several cancers [14-17], there are many cancers that fail to respond to anti-PD-1/PD-L1 therapies. A recent clinical trial (Phase 1b KEYNOTE-028) in 22 advanced PTCs and follicular thyroid cancers evaluated the safety and antitumor activity of pembrolizumab as monotherapy. Only two patients showed a partial response (overall response rate $=9 \%$ ) [18]. This might be explained by the ability of PD-L1 to regulate tumor cells in an immune-independent manner $[19,20]$. Indeed, several reports have shown that PD-L1 could be involved in regulation of signaling pathways [21-24].

PTC is a predominantly MAP kinase signaling pathway-driven cancer [25]. The BRAFV600E mutations represent the most common genetic alteration in PTC and they has been shown to predict PTC aggressiveness and patient prognosis $[3,26]$. Increased PD-L1 expression has been shown previously to be associated with BRAFV600E point mutation in several cancers including thyroid cancer [27-29]. Moreover, a recent report has demonstrated that BRAFV600E mutation can upregulate PD-L1 expression, which further supports the non-immune function of PD-L1 [30].

The level of PD-L1 expression in PTC and overall prognosis have shown conflicting data [31-33]. However, information about PD-L1 expression in PTCs from people of Middle Eastern ethnicity (where PTC prevalence is very high) has never been explored before. Therefore, we conducted a comprehensive analysis to evaluate the clinico-pathological and prognostic significance of PD-L1 expression in a large cohort of Middle Eastern PTC patients. Given the significant association of PD-L1 and BRAFV600E mutation in our cohort, we explored whether PD-L1 is regulated by BRAFV600E using PTC cell lines.

\section{Results}

2.1. Programmed Cell Death Ligand 1 (PD-L1) Expression in Papillary Thyroid Carcinoma (PTC) and Its Clinico-Pathological Associations

PD-L1 protein expression was assessed immunohistochemically in 1512 PTC samples. However, immunohistochemistry data were interpretable in 1458 samples and hence were included for further analysis. PD-L1 over-expression was noted in 32.4\% (473/1458) of cases (Table 1; Figure 1). A significant association was noted between PD-L1 over-expression and aggressive clinico-pathological characteristics such as tall cell variant $(p<0.0001)$, extrathyroidal extension $(p=0.0203)$ and lymph node metastasis $(p=0.0466)$ (Table 1$)$. Importantly, we also found a significant association between PD-L1 over-expression and poor diseasefree survival (DFS; $p<0.0001$ ), as well as poor recurrence-free survival (RFS; $p=0.0006$ ) (Table 1; Figure 2A,B), but not overall survival $(p=0.0921)$. On multivariate analysis, PD-L1 was found to be an independent predictor of DFS (HR $=2.16$; $95 \% \mathrm{CI}=1.73-2.72$; $p<0.0001)$ and $\mathrm{RFS}(\mathrm{HR}=1.59 ; 95 \% \mathrm{CI}=1.22-2.05 ; p=0.0005)$ (Table 2$)$. 
Table 1. Association of clinico-pathological characteristics with PD-L1 expression in papillary thyroid carcinoma.

\begin{tabular}{|c|c|c|c|c|c|c|c|}
\hline & \multicolumn{2}{|c|}{ Total } & \multicolumn{2}{|c|}{ PD-L1 High } & \multicolumn{2}{|c|}{ PD-L1 Low } & \multirow[t]{2}{*}{$p$ Value } \\
\hline & No. & $\%$ & No. & $\%$ & No. & $\%$ & \\
\hline No. of Patients & 1458 & & 473 & 32.4 & 985 & 67.6 & \\
\hline \multicolumn{8}{|l|}{ Age (Years) } \\
\hline$<55$ & 1189 & 81.5 & 389 & 32.7 & 800 & 67.3 & 0.6365 \\
\hline$\geq 55$ & 269 & 18.5 & 84 & 31.2 & 185 & 68.8 & \\
\hline \multicolumn{8}{|l|}{ Sex } \\
\hline Female & 1102 & 75.6 & 370 & 33.6 & 732 & 66.4 & 0.1014 \\
\hline Male & 356 & 24.4 & 103 & 28.9 & 253 & 71.1 & \\
\hline \multicolumn{8}{|c|}{ Extrathyroidal Extension } \\
\hline Absent & 834 & 57.2 & 250 & 30.0 & 584 & 70.0 & $0.0203(0.0271) *$ \\
\hline Present & 624 & 42.8 & 223 & 35.7 & 401 & 64.3 & \\
\hline \multicolumn{8}{|l|}{$\mathrm{pT}$} \\
\hline pT1 & 400 & 28.5 & 130 & 32.5 & 270 & 67.5 & 0.5456 \\
\hline pT2 & 298 & 21.2 & 89 & 29.9 & 209 & 70.1 & \\
\hline pT3 & 595 & 42.4 & 204 & 34.3 & 391 & 65.7 & \\
\hline pT4 & 110 & 7.8 & 33 & 30.0 & 77 & 70.0 & \\
\hline \multicolumn{8}{|l|}{$\mathrm{pN}$} \\
\hline $\mathrm{pN} 0$ & 582 & 44.4 & 176 & 30.2 & 406 & 69.8 & $0.0466(0.0466)$ * \\
\hline $\mathrm{pN} 1$ & 728 & 55.6 & 258 & 35.4 & 470 & 64.6 & \\
\hline \multicolumn{8}{|l|}{$\mathrm{pM}$} \\
\hline $\mathrm{pM} 0$ & 1401 & 96.1 & 454 & 32.4 & 947 & 67.6 & 0.8836 \\
\hline $\mathrm{pM} 1$ & 57 & 3.9 & 19 & 33.3 & 38 & 66.7 & \\
\hline \multicolumn{8}{|l|}{ Stage } \\
\hline I & 1188 & 84.3 & 380 & 32.0 & 808 & 68.0 & 0.9322 \\
\hline II & 152 & 10.8 & 53 & 34.9 & 99 & 65.1 & \\
\hline III & 19 & 1.4 & 6 & 31.6 & 13 & 68.4 & \\
\hline IVA & 19 & 1.4 & 5 & 26.3 & 14 & 73.7 & \\
\hline IVB & 30 & 2.1 & 10 & 33.3 & 20 & 66.7 & \\
\hline \multicolumn{8}{|l|}{ Histology Type } \\
\hline Classical Variant & 955 & 65.5 & 334 & 35.0 & 621 & 65.0 & $<0.0001(<0.0001) *$ \\
\hline Follicular Variant & 258 & 17.7 & 54 & 20.9 & 204 & 79.1 & \\
\hline Tall Cell Variant & 135 & 9.3 & 54 & 40.0 & 81 & 60.0 & \\
\hline Other Variants & 110 & 7.5 & 31 & 28.2 & & 71.8 & \\
\hline \multicolumn{8}{|l|}{$B R A F$ Mutation } \\
\hline Yes & 707 & 56.2 & 250 & 35.4 & 457 & 64.6 & $0.0183(0.0271) *$ \\
\hline No & 550 & 43.8 & 160 & 29.1 & 390 & 70.9 & \\
\hline \multicolumn{8}{|l|}{ Disease-Free Survival } \\
\hline 5 years & & & 266 & 62.2751 & & 79.2 & $<0.0001$ \\
\hline \multicolumn{8}{|c|}{ Recurrence-Free Survival } \\
\hline
\end{tabular}

* $p$ values in parentheses represent the Benjamini-Hochberg post hoc test $p$ values. pT-pathologic tumor size; $\mathrm{pN}$ - pathologic lymphnode metastasis; pM - pathologic distant metastasis; PD-L1—Programmed Cell Death Ligand 1. 


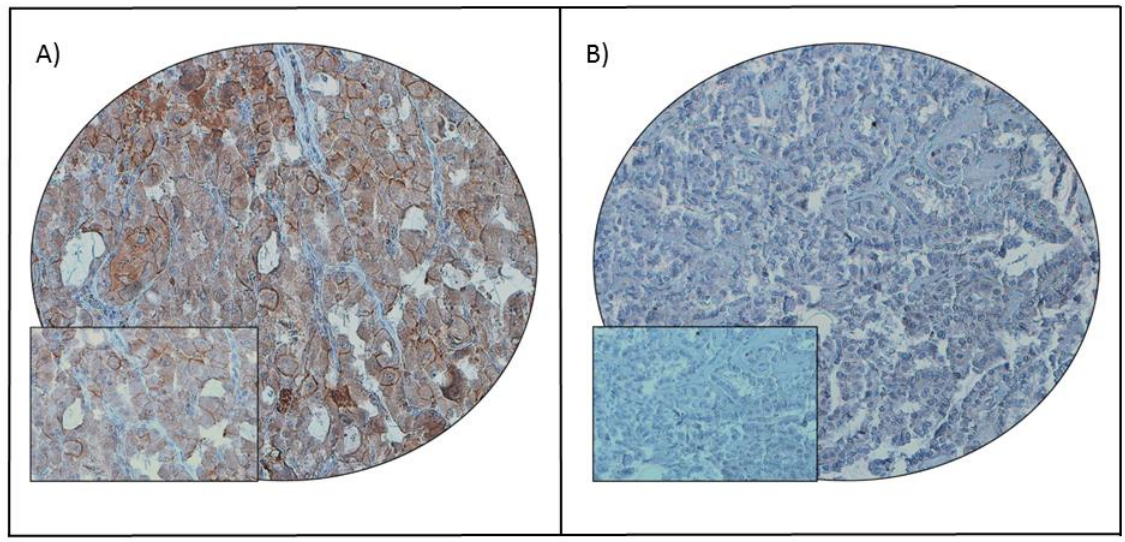

Figure 1. PD-L1 immunohistochemical staining in papillary thyroid carcinoma (PTC) tissue microarray (TMA). Representative examples of tumors showing (A) high expression and (B) low expression (right panel) of PD-L1. A $20 \times / 0.70$ objective on an Olympus BX 51 microscope (Olympus America Inc., Center Valley, PA, USA) with the inset showing a $40 \times 0.85$ aperture magnified view of the same TMA spot.

Table 2. Cox regression model analysis for prediction of disease-free survival and recurrence-free survival.

\begin{tabular}{|c|c|c|c|c|c|c|c|c|}
\hline \multirow[b]{3}{*}{ Clinico-pathological Variables } & \multicolumn{4}{|c|}{ Disease-Free Survival } & \multicolumn{4}{|c|}{ Recurrence-Free Survival } \\
\hline & \multicolumn{2}{|c|}{ Univariate } & \multicolumn{2}{|c|}{ Multivariate } & \multicolumn{2}{|c|}{ Univariate } & \multicolumn{2}{|c|}{ Multivariate } \\
\hline & $\begin{array}{l}\text { Risk Ratio } \\
(95 \% \mathrm{CI})\end{array}$ & $p$ Value & $\begin{array}{l}\text { Risk Ratio } \\
(95 \% \mathrm{CI})\end{array}$ & $p$ Value & $\begin{array}{l}\text { Risk Ratio } \\
(95 \% \mathrm{CI})\end{array}$ & $p$ Value & $\begin{array}{c}\text { Risk Ratio } \\
(95 \% \mathrm{CI})\end{array}$ & $p$ Value \\
\hline $\begin{array}{c}\text { Age } \\
\text { Above } \geq 55 \text { years } \\
\text { (vs. }<55 \text { years) }\end{array}$ & $\begin{array}{c}2.54 \\
(2.03-3.16)\end{array}$ & $<0.0001 *$ & $\begin{array}{c}2.13 \\
(1.59-2.87)\end{array}$ & $<0.0001 *$ & $\begin{array}{c}2.97 \\
(2.31-3.80)\end{array}$ & $<0.0001 *$ & $\begin{array}{c}2.65 \\
(1.90-3.70)\end{array}$ & $<0.0001 *$ \\
\hline $\begin{array}{c}\text { Sex } \\
\text { Male (vs. Female) }\end{array}$ & $\begin{array}{c}0.59 \\
(0.48-0.73)\end{array}$ & $<0.0001 *$ & $\begin{array}{c}0.67 \\
(0.52-0.86)\end{array}$ & $0.0016 *$ & $\begin{array}{c}0.56 \\
(0.44-0.71)\end{array}$ & $<0.0001 *$ & $\begin{array}{c}0.71 \\
(0.53-0.95)\end{array}$ & $0.0224 *$ \\
\hline $\begin{array}{c}\text { Histology } \\
\text { Tall Cell Variant } \\
\text { (vs. Other Variants) }\end{array}$ & $\begin{array}{c}1.94 \\
(1.41-2.61)\end{array}$ & $<0.0001 *$ & $\begin{array}{c}1.48 \\
(1.04-2.05)\end{array}$ & $0.0236 *$ & $\begin{array}{c}1.27 \\
(0.84-1.83)\end{array}$ & 0.2528 & $\begin{array}{c}0.93 \\
(0.59-1.40)\end{array}$ & 0.7422 \\
\hline $\begin{array}{l}\text { Extrathyroidal Extension } \\
\text { Present (vs. Absent) }\end{array}$ & $\begin{array}{c}2.27 \\
(1.82-2.86)\end{array}$ & $<0.0001 *$ & $\begin{array}{c}1.40 \\
(1.07-1.82)\end{array}$ & $0.0149 *$ & $\begin{array}{c}2.92 \\
(2.24-3.85)\end{array}$ & $<0.0001 *$ & $\begin{array}{c}1.72 \\
(1.25-2.36)\end{array}$ & $0.0008 *$ \\
\hline $\begin{array}{c}\text { Lymph Node Metastasis } \\
\text { N1 (vs. N0) }\end{array}$ & $\begin{array}{c}2.33 \\
(1.84-2.96)\end{array}$ & $<0.0001 *$ & $\begin{array}{c}1.72 \\
(1.30-2.26)\end{array}$ & $0.0001 *$ & $\begin{array}{c}2.74 \\
(2.09-3.63)\end{array}$ & $<0.0001 *$ & $\begin{array}{c}2.31 \\
(1.65-3.23)\end{array}$ & $<0.0001 *$ \\
\hline $\begin{array}{c}\text { Distant Metastasis Present } \\
\text { (vs. Absent) }\end{array}$ & $\begin{array}{c}3.99 \\
(2.83-5.62)\end{array}$ & $<0.0001 *$ & $\begin{array}{c}2.29 \\
(1.43-3.69)\end{array}$ & $0.0006 *$ & $\begin{array}{c}6.14 \\
(4.25-8.62)\end{array}$ & $<0.0001 *$ & $\begin{array}{c}2.78 \\
(1.68-4.60)\end{array}$ & $<0.0001 *$ \\
\hline $\begin{array}{c}\text { Stage } \\
\text { IV (vs. I-III) }\end{array}$ & $\begin{array}{c}3.62 \\
(2.39-5.27)\end{array}$ & $<0.0001 *$ & $\begin{array}{c}0.83 \\
(0.46-1.49)\end{array}$ & 0.5305 & $\begin{array}{c}6.25 \\
(4.12-9.10)\end{array}$ & $<0.0001 *$ & $\begin{array}{c}0.81 \\
(0.44-1.52)\end{array}$ & 0.5164 \\
\hline $\begin{array}{c}\text { PD-L1 } \\
\text { High (vs. Low) }\end{array}$ & $\begin{array}{c}2.04 \\
(1.66-2.52)\end{array}$ & $<0.0001 *$ & $\begin{array}{c}2.08 \\
(1.65-2.62)\end{array}$ & $<0.0001 *$ & $\begin{array}{c}1.51 \\
(1.19-1.92)\end{array}$ & $0.0008 *$ & $\begin{array}{c}1.54 \\
(1.18-2.00)\end{array}$ & $0.0013 *$ \\
\hline
\end{tabular}

* Significant $p$ value.

Interestingly, we found an association between PD-L1 over-expression and $B R A F$ mutation ( $p=0.0183$ ) (Table 1 ). Since BRAFV600E mutation is known to play a role in the pathogenesis and prognosis of PTC, we sought to determine whether the prognostic associations were independently driven by PDL1 expression rather than co-existing BRAFV600E mutation. Using Kaplan-Meier analysis, we found that cases with co-existing PD-L1 over-expression and BRAF mutation had a significantly worse DFS compared to cases with $B R A F$ mutation alone $(p<0.0001)$ (Figure $2 \mathrm{C})$. 
A

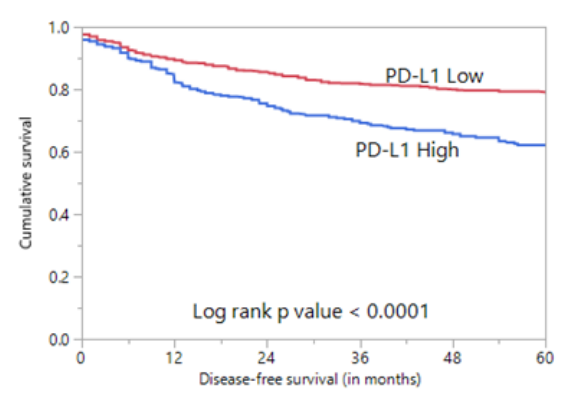

C

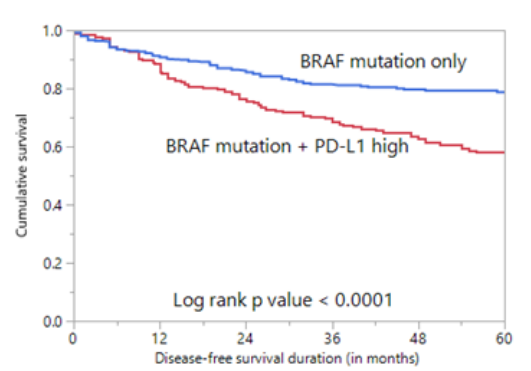

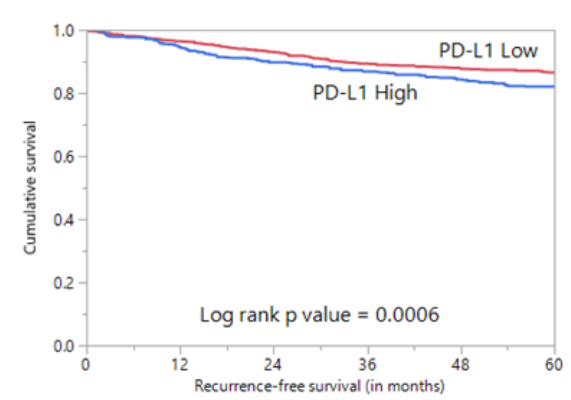

D

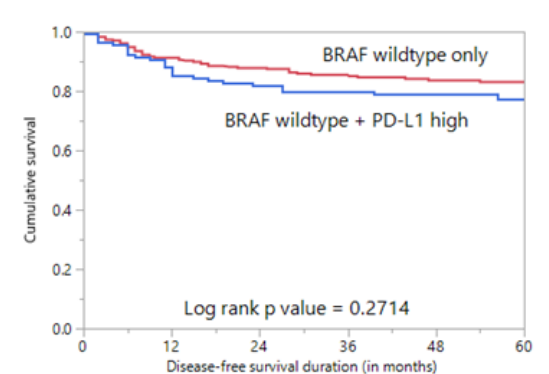

E

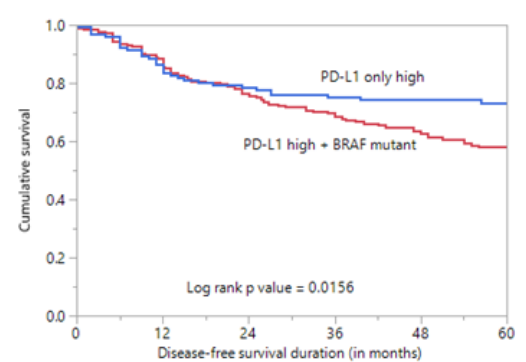

Figure 2. Survival analysis of PD-L1 protein expression. (A) Kaplan-Meier survival plot showing statistically significant poor disease-free survival in PD-L1 high-expression cases compared to PD-L1 low expression $(p<0.0001)$. (B) Kaplan-Meier survival plot showing statistically significant poor recurrence-free survival in PD-L1 high-expression cases compared to PD-L1 low expression $(p=0.0006)$. (C) Kaplan-Meier survival plot showing statistically significant poor disease-free survival in cases with co-existing PD-L1 expression and BRAF mutation compared to cases with BRAF mutation alone $(p<0.0001)$. (D) Kaplan-Meier survival plot shows no statistically significant difference in disease-free survival in cases with co-existing PD-L1 expression and wildtype BRAF compared to cases with wildtype $B R A F$ alone $(p=0.2714)$. (E) Kaplan-Meier survival plot showing statistically significant poor disease-free survival in cases with co-existing PD-L1 expression and $B R A F$ mutation compared to cases with PD-L1 expression alone $(p=0.0156)$.

\subsection{BRAF Mutation and Its Association with PD-L1 in PTC In Vitro}

Our clinical data showed a significant association between PD-L1 over-expression and $B R A F$ mutation. To test this association in vitro, we analyzed the basal expression of PD-L1 in PTC cell lines by immuno-blotting. We found high expression of PD-L1 in $B R A F$-mutated PTC cell lines (BCPAP and K1) compared to a wildtype BRAF PTC cell line (TPC-1) (Figure 3A,B). We also found increased expression of pMEK1/2 and $\mathrm{pERK} 1 / 2$ in $B R A F$-mutated cell lines compared to a wildtype cell line (Figure 3A,B). Next, we inhibited BRAF using vemurafenib and analyzed the expression of PD-L1, pMEK1/2 and pERK1/2 in BRAF-mutated cell lines. As shown in Figure 3C,D, inhibition of BRAF induced PD-L1, pMEK1/2 and pERK1/2 expressions in BRAF-mutated cell lines. However, vemurafenib treatment did not affect the colony-forming ability of PTC cells, as shown by clonogenicity assay (Figure 3E,F). 


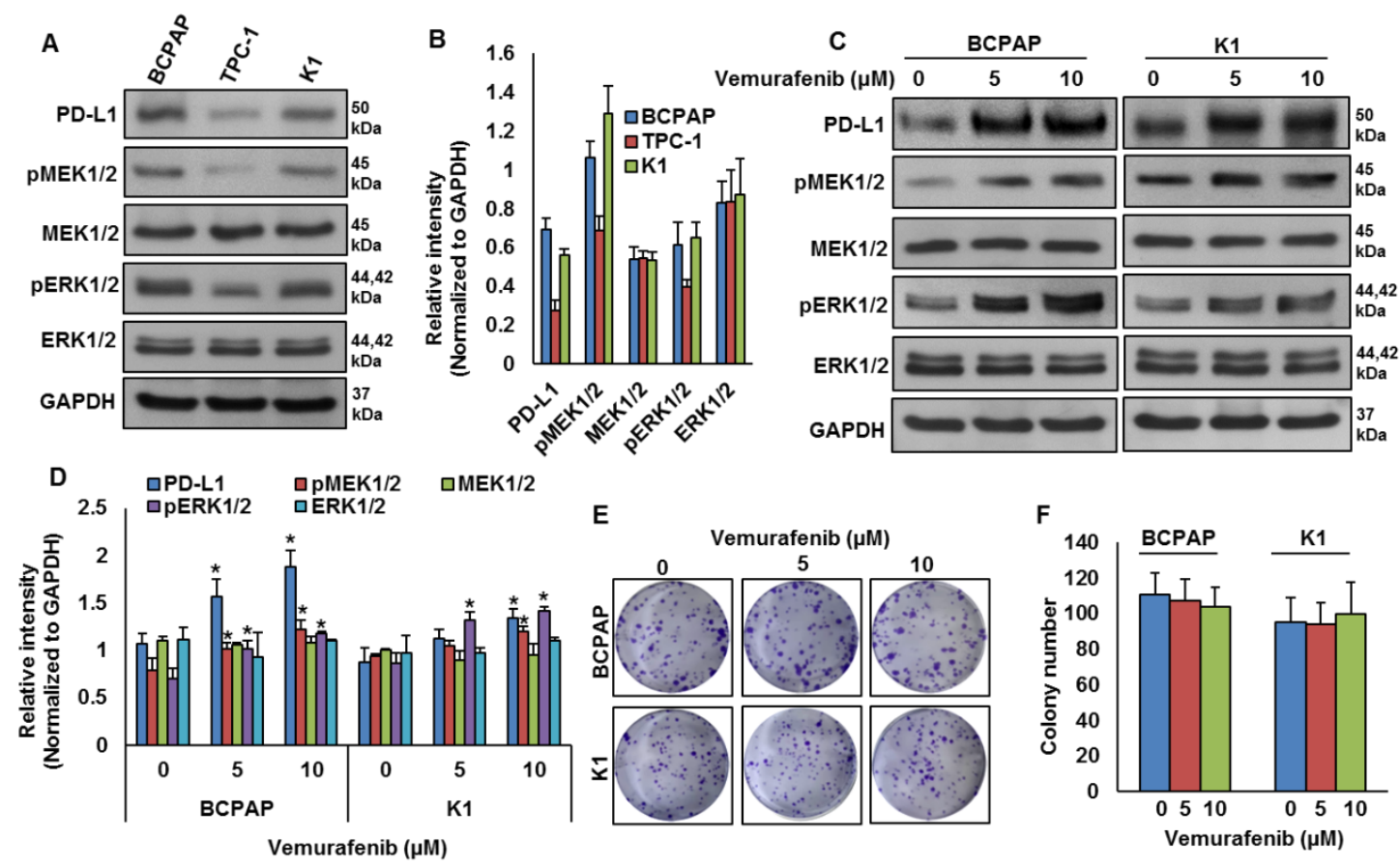

Figure 3. BRAF mutation and its association with PD-L1 in PTC in vitro. (A,B) Basal expression of PD-L1 in PTC cell lines. Proteins were isolated from three PTC cell lines and immuno-blotted with antibodies against PD-L1, pMEK1/2, MEK1/2, pERK1/2, ERK1/2 and GAPDH. Western blots were quantified and data are presented as mean \pm SD of three independent experiments $(n=3)$. (C,D) BRAF inhibition increases PD-L1 expression. BRAF-mutated PTC cell lines were treated with indicated doses of vemurafenib for $48 \mathrm{~h}$. After cell lysis, equal amounts of proteins were separated by SDS-PAGE, transferred to immobilon membrane, and immuno-blotted with antibodies against PD-L1, pMEK1/2, MEK1/2, pERK1/2, ERK1/2 and GAPDH as indicated. Western blots were quantified and data are presented as mean \pm SD of three independent experiments $(n=3) .{ }^{*}$ Indicates a statistically significant difference compared to control with $p<0.05$. (E,F) BRAF inhibition on cell growth. BRAF-mutated PTC cell lines were treated with indicated doses of vemurafenib for $48 \mathrm{~h}$. Cells $\left(5 \times 10^{2}\right)$ were then re-seeded into a 6-well plate, and grown for an additional 6-8 days, then stained with crystal violet and colonies were counted. Data presented in the bar graphs are the mean $\pm \mathrm{SD}$ of three independent experiments $(n=3)$ which were repeated at least two times with the same results. ${ }^{*}$ Indicates a statistically significant difference compared to control with $p<0.05$.

\subsection{Mitogen-Activated Protein Kinase Kinase (MEK) Inhibition Decreases PD-L1 Expression}

To test the effect of MEK inhibition on PD-L1 expression, $B R A F$-mutated cell lines were treated with a pharmacologic inhibitor for MEK, selumetinib, for $48 \mathrm{~h}$ and the expressions of PD-L1, pMEK1/2 and pERK1/2 were analyzed by immuno-blotting. As shown in Figure $4 \mathrm{~A}, \mathrm{~B}$, inhibition of MEK by selumetinib prominently downregulated the expressions of PD-L1, pMEK1/2 and pERK1/2 in BRAF-mutated cell lines in a dose-dependent manner. Furthermore, clonogenic ability was significantly reduced post-selumetinib treatment as compared to untreated control (Figure 4C,D). 
A

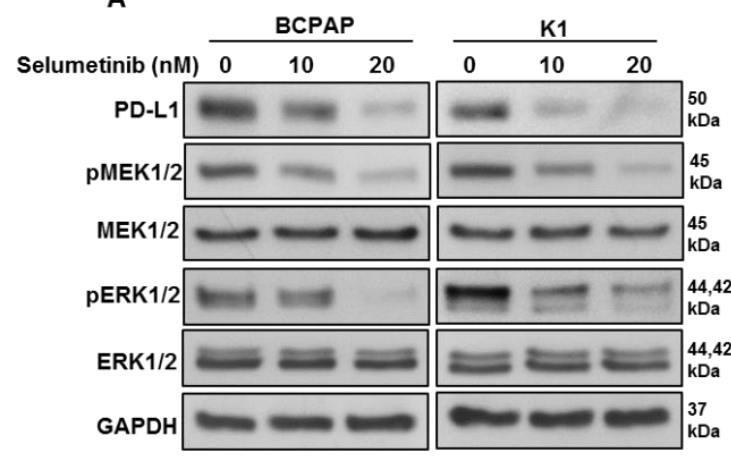

C

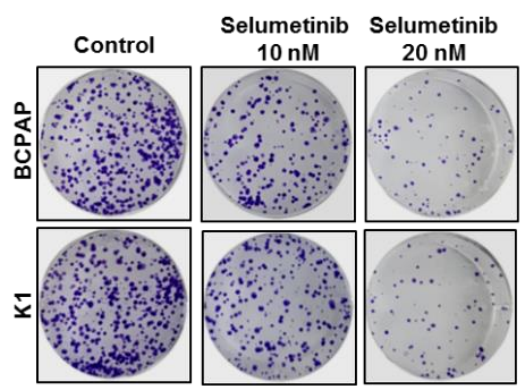

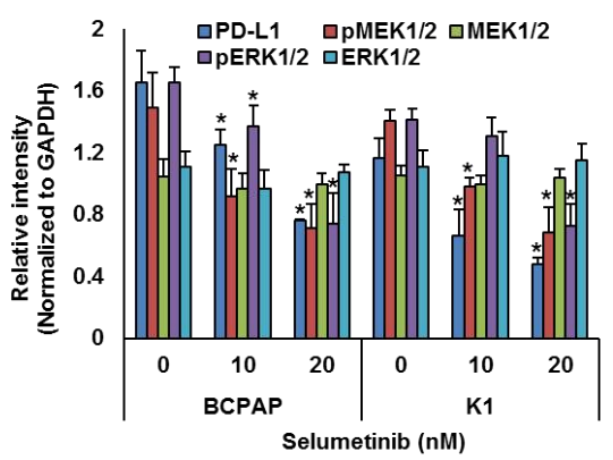

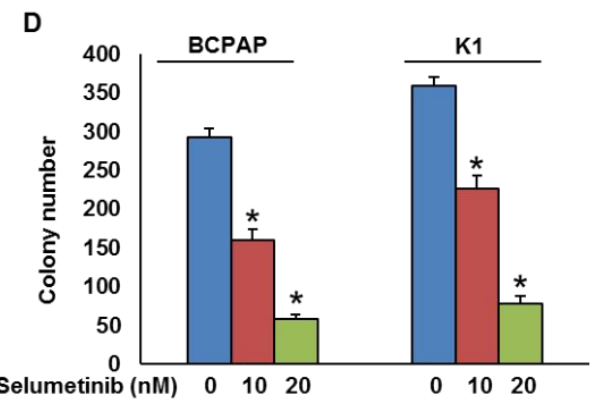

Figure 4. MEK inhibition downregulates PD-L1 expression and decreases cell growth. (A,B) MEK inhibition downregulates PD-L1 expression. BRAF-mutated cells were treated with indicated doses of selumetinib for $48 \mathrm{~h}$. After cell lysis, equal amounts of proteins were separated by SDS-PAGE, transferred to immobilon membrane, and immuno-blotted with antibodies against PD-L1, pMEK1/2, MEK1/2, pERK1/2, ERK1/2 and GAPDH as indicated. Western blots were quantified and data are presented as mean $\pm \mathrm{SD}$ of three independent experiments $(n=3)$. ${ }^{*}$ Indicates a statistically significant difference compared to control with $p<0.05$. (C,D) MEK inhibition decreases cell growth. BRAF-mutated PTC cell lines were treated with indicated doses of selumetinib for $48 \mathrm{~h}$. Cells $\left(5 \times 10^{2}\right)$ were then re-seeded into a 6-well plate, and grown for an additional 6-8 days, then stained with crystal violet and colonies were counted. Data presented in the bar graphs are the mean \pm SD of three independent experiments $(n=3)$ which were repeated at least two times with the same results.

* Indicates a statistically significant difference compared to control with $p<0.05$.

\subsection{Downregulation of PD-L1 Decreases Cell Growth of BRAF-Mutated Cell Lines}

We showed that PD-L1 over-expression was significantly associated with BRAF mutation and poor survival in PTC patient samples. Therefore, we sought to determine whether targeting PD-L1 expression would be a viable therapeutic strategy to inhibit growth of $B R A F$-mutated cells. We knocked down PD-L1 in BRAF-mutated cells using specific siRNA and analyzed the cell growth by a clonogenicity assay. Knockdown of PDL1 using two different siRNA sequences significantly decreased the clonogenic ability of PTC cells after $48 \mathrm{~h}$ of transfection (Figure 5A,B). In addition, silencing of PD-L1 decreased AKT-Ser (473) phosphorylation, and downregulated anti-apoptotic proteins bcl2 and bcl-xL, as well as induced cleavage of caspase-3 and PARP, in BRAF-mutated cell lines (Figure 5C,D). However, knockdown of PD-L1 did not change the expressions of pMEK1/2 and pERK1/2, showing that PD-L1 functions downstream of the MEK/ERK signaling cascade (Figure 5E,F). 

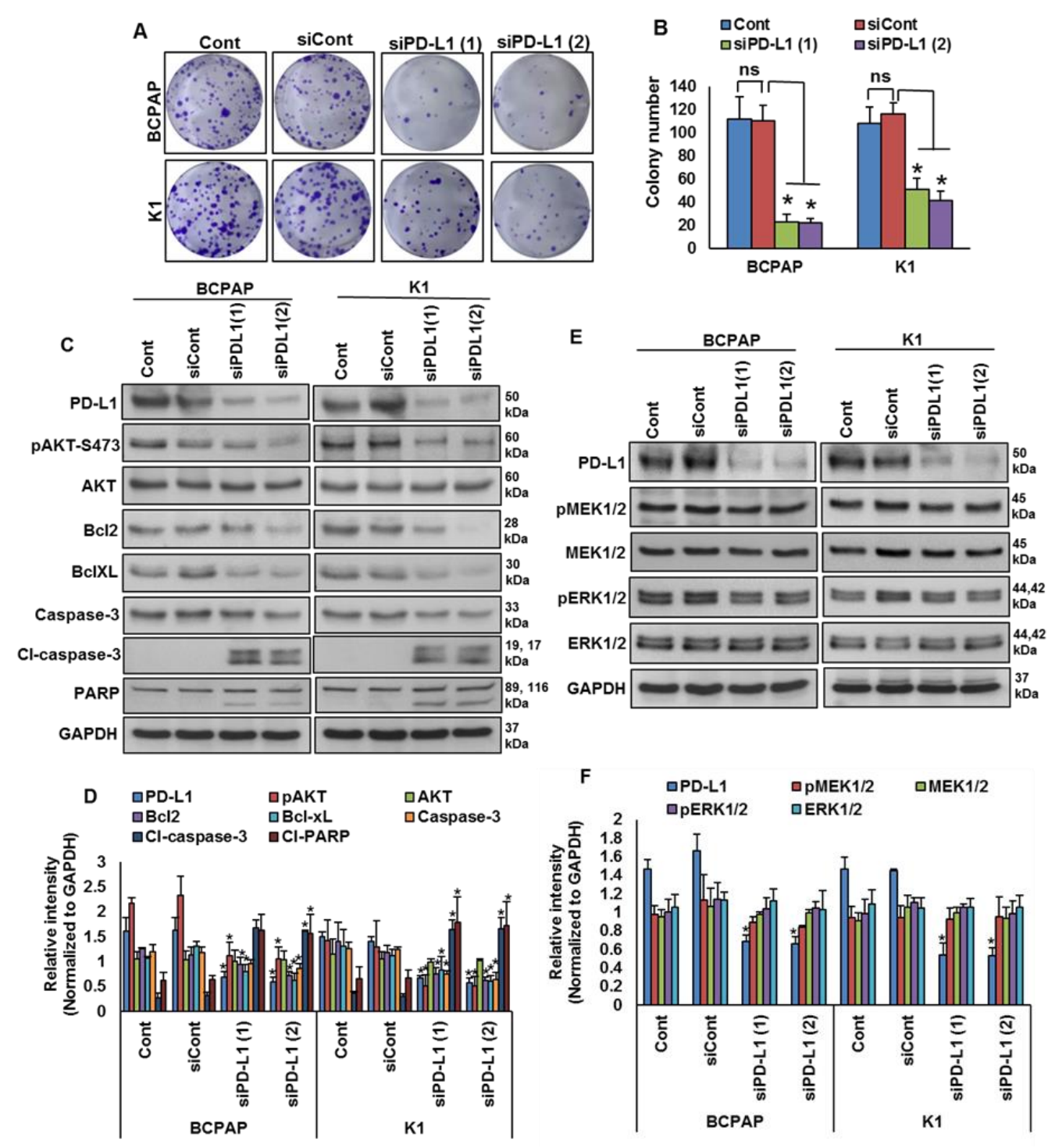

Figure 5. Silencing of PD-L1 decreases cell growth of BRAF-mutated cell lines. (A,B) Knockdown of PD-L1 decreases clonogenicity. BRAF-mutated PTC cells were transfected with scrambled siRNA and two different PD-L1 siRNAs (50 nM). Forty-eight hours post-transfection, cells $\left(5 \times 10^{2}\right)$ were re-seeded into a 6-well plate, and grown for an additional 6-8 days, then stained with crystal violet and colonies were counted. Data presented in the bar graphs are the mean \pm SD of three independent experiments $(n=3)$, which were repeated at least two times with the same results. ${ }^{*}$ Indicates a statistically significant difference compared to siRNA control with $p<0.05$. (C,D) Knockdown of PD-L1 decreases AKT phosphorylation and downregulates the expression of anti-apoptotic proteins and induces the cleavage of caspase-3 and PARP. BRAFmutated PTC cells were transfected with scrambled siRNA and two different PD-L1 siRNAs (50 nM). Forty-eight hours post-transfection, cells were lysed and equal amounts of proteins were separated and immuno-blotted with antibodies against PD-L1, pAKT, AKT, Bcl-2, Bcl-xL, caspase-3, cleaved caspase-3, PARP and GAPDH as indicated. Western blots were quantified and data are presented as mean $\pm \mathrm{SD}$ of three independent experiments $(n=3) .{ }^{*}$ Indicates a statistically significant difference compared to siControl with $p<0.05$. (E,F) Knockdown of PD-L1 caused no effect on MEK/ERK activation. BRAF-mutated PTC cells were transfected with scrambled siRNA and two different PD-L1 siRNAs (50 nM). Forty-eight hours post-transfection, cells were lysed and equal amounts of proteins were separated and immuno-blotted with antibodies against PD-L1, pMEK1/2, MEK1/2, pERK1/2, ERK1/2 and GAPDH. Western blots were quantified and data are presented as mean \pm SD of three independent experiments $(n=3)$. ${ }^{*}$ Indicates a statistically significant difference compared to siControl with $p<0.05$. 


\section{Discussion}

PTC accounts for more than $80 \%$ of all thyroid cancers and is typically associated with a favorable prognosis [34-36]. Aside from radioactive therapy, which is the standard care, there are limited therapeutic options available for the small percentage of patients who have aggressive PTC and eventually develop resistance to radioactive iodine treatment [37,38]. Recently, treatment with PD-1/PD-L1 inhibitors has demonstrated a therapeutic effect in several aggressive tumors [11-13]. PD-L1 expression has been used to identify patients who are likely to respond to anti-PD-L1 therapies [39,40]. Furthermore, PD-L1 expression has emerged as a potential prognostic marker in several solid tumors including thyroid cancer [31,41-44]. In this study, we evaluated the association between PD-L1 over-expression and clinico-pathological markers as well as survival in patients with PTC. Analyzing more than 1400 Middle Eastern PTC patients from a single institute demonstrated the prognostic value of PD-L1 expression in these patients.

We found a statically significant correlation between higher levels of PD-L1 expression and lymph node metastasis, extrathyroidal extension, tall cell variant, DFS and RFS. Several previous studies evaluated the diagnostic and prognostic value of PD-L1 expressions in thyroid cancer without reaching consensus [31-33,45]. These conflicting data could be attributed to several factors, including sample size, antibody used, cut-off values applied and ethnicity of the patients. Analogous to our findings, a study of 185 PTCs from Canada showed a significantly shorter median DFS in PD-L1-positive tumors compared to PD-L1negative tumors [33]. Similarly, another study on 260 PTC cases showed a significantly worse RFS in PD-L1-positive tumors in multivariate Cox regression analysis [31].

Interestingly, we found a significant positive association between PD-L1 expression and the presence of BRAFV600E mutations, which is known to play a major role in PTC pathogenesis and aggressiveness. This led us to question whether the prognostic associations were independently driven by PD-L1 expression rather than co-existing BRAFV600E mutation because $>50 \%$ of PD-L1-positive PTC samples had co-existing BRAFV600E mutations. Specifically, we compared the DFS in cases with coexisting PD-L1 expression and BRAFV600E mutation to those with BRAFV600E mutation alone and found the former to be associated with significantly poorer DFS $(p<0.0001)$. This finding could support a previous report highlighting the ability of BRAFV600E signaling to modulate the immune response [29]. Interestingly, a recent study in colorectal cancer (CRC) has shown that $B R A F V 600 E$ can transcriptionally upregulate PD-L1 expression and enhance apoptosis which might indicate an intrinsic non-immune function of PD-L1 [30].

Thus, we determined whether BRAFV600E can regulate PD-L1 expression in human PTC cell lines. Our in vitro studies confirmed the association of high PD-L1 expression in the PTC-BRAF-mutated cell lines. Vemurafenib treatment of the BRAF-mutated cell lines induces PD-L1 expression, as shown by western blotting, without affecting cell viability. The mitogen activated protein kinase (MAPK) pathway has been shown to regulate PD-L1 expression in various cancers [46-48]. In PTC cell lines, we showed that MEK inhibition downregulated PD-L1 expression and decreased the cell growth. In addition, our in vitro data support the ability of PD-L1 to regulate apoptosis in PTC. This insight into the role of PD-L1 in regulating apoptosis has been reported previously in a limited number of solid tumor cell lines [30,49-51].

\section{Materials and Methods}

\subsection{Sample Selection}

One thousand four-hundred and fifty-eight PTC patients diagnosed between 1989 and 2018 at King Faisal Specialist Hospital and Research Center (Riyadh, Saudi Arabia) with available archival tissue samples were included in the study. Clinico-pathological data were collected from case records, the details of which are summarized in Table 3. The Institutional Review Board of the hospital provided approval for the collection of archival samples. For this study, since only archival paraffin tissue blocks were used, a waiver of 
consent was obtained from the Research Advisory Council (RAC) on 06 February 2012 (RAC\# 2110 031).

Table 3. Clinico-pathological variables for the patient cohort $(n=1458)$.

\begin{tabular}{|c|c|}
\hline Clinico-Pathological Variables & $n(\%)$ \\
\hline \multicolumn{2}{|l|}{ Age } \\
\hline Median & 38.0 \\
\hline Range (IQR)^ & $29.0-50.0$ \\
\hline$<55$ years & $1189(81.5)$ \\
\hline$\geq 55$ years & $269(18.5)$ \\
\hline \multicolumn{2}{|l|}{ Gender } \\
\hline Female & $1102(75.6)$ \\
\hline Male & $356(24.4)$ \\
\hline \multicolumn{2}{|l|}{ Histopathology } \\
\hline Classical Variant & $955(65.5)$ \\
\hline Follicular Variant & $258(17.7)$ \\
\hline Tall Cell Variant & $135(9.3)$ \\
\hline Others & $110(7.5)$ \\
\hline \multicolumn{2}{|l|}{ Extrathyroidal Extension } \\
\hline Absent & $834(57.2)$ \\
\hline Present & $624(42.8)$ \\
\hline \multicolumn{2}{|l|}{ pT } \\
\hline $\mathrm{T} 1$ & $400(27.4)$ \\
\hline $\mathrm{T} 2$ & $298(20.4)$ \\
\hline $\mathrm{T} 3$ & $595(40.9)$ \\
\hline $\mathrm{T} 4$ & $110(7.5)$ \\
\hline Unknown & $55(3.8)$ \\
\hline \multicolumn{2}{|l|}{$\mathrm{pN}$} \\
\hline No & $582(39.9)$ \\
\hline N1 & $728(49.9)$ \\
\hline $\mathrm{Nx}$ & $148(10.2)$ \\
\hline \multicolumn{2}{|l|}{$\mathrm{pM}$} \\
\hline M0 & $1401(96.1)$ \\
\hline M1 & $57(3.9)$ \\
\hline \multicolumn{2}{|l|}{ Stage } \\
\hline I & $1188(81.5)$ \\
\hline II & $152(10.4)$ \\
\hline III & $19(1.3)$ \\
\hline IVA & $19(1.3)$ \\
\hline IVB & $30(2.1)$ \\
\hline Unknown & $50(3.4)$ \\
\hline \multicolumn{2}{|l|}{$B R A F$ Mutation } \\
\hline Present & $707(48.5)$ \\
\hline Absent & $550(37.7)$ \\
\hline Unknown & $201(13.8)$ \\
\hline \multicolumn{2}{|l|}{ RAI Therapy } \\
\hline Yes & $1113(76.3 \%)$ \\
\hline No & 345 (23.7) \\
\hline
\end{tabular}

\subsection{DNA Isolation}

DNA was extracted from PTC formalin-fixed and paraffin-embedded (FFPE) tumor tissues utilizing a Gentra DNA isolation kit (Gentra, Minneapolis, MN, USA) according to manufacturer's protocols, as elaborated in a previous study [52]. 


\subsection{Sanger Sequencing Analysis}

Sequencing of entire coding and splicing regions of exon 15 in the BRAF gene from 1257 PTC samples was carried out using Sanger sequencing technology. Primer 3 online software was utilized to design the primers (BRAF-EX15F1: AAACTCTTCATAATGCTTGCTCTG, BRAF-EX15R1: TTTCTAGTAACTCAGCAGCATCTCA). PCR and Sanger sequencing analyses were carried out as described previously [53]. A reference sequence was downloaded from NCBI GenBank. Sequencing results were compared with the reference sequence by Mutation Surveyor V4.04 (Soft Genetics, LLC, State College, PA, USA).

\subsection{Tissue Microarray (TMA) Construction and Immunohistochemistry (IHC)}

A tissue microarray (TMA) format was utilized for immunohistochemical analysis of the PTC samples. TMA was constructed as previously described [54]. Briefly, a modified semiautomatic robotic precision instrument (Beecher Instruments, Woodland, WI, USA) was used to punch tissue cylinders with a diameter of $0.6 \mathrm{~mm}$ from a representative tumor area of the donor tissue block and brought into the recipient paraffin block. Two $0.6 \mathrm{~mm}$ cores of PTC were arrayed from each case.

Tissue microarray slides were processed and stained manually as described previously [55]. Primary antibody against PD-L1 (E1L3N, 1:50 dilution, pH 9.0, Cell Signaling Technology, Danvers, MA, USA) was used. A membranous and/or cytoplasmic staining was observed. Only the membrane staining was considered for scoring. PD-L1 was scored as described previously [56]. Briefly, the proportion of positively stained cells was calculated as a percentage for each core and the scores were averaged across two tissue cores from the same tumor to yield a single percent staining score representing each cancer patient. For the purpose of statistical analysis, the scores were dichotomized. Cases showing an expression level of $\geq 5 \%$ were classified as over-expression and those with less than $5 \%$ as low expression. Only staining of tumor cells (not lymphocytes) was considered for percentage calculation.

\subsection{Cell Culture}

The PTC cell line BCPAP was obtained from Deutsche Sammlung von Mikroorganismen und Zellkulturen (DSMZ, Braunschweig, Germany), and TPC-1 was kindly provided by Dr. Bryan McIver (Department of Endocrinology, Mayo Clinic, Rochester, MN, USA). The K1 cell line was purchased from the American Type Culture Collection (ATCC, Manassas, VA, USA). Cell lines were cultured in RPMI 1640 media supplemented with $10 \%$ fetal bovine serum (FBS), 100 units/mL penicillin/streptomycin and 100 units/mL glutamine. These cell lines were authenticated in-house using short tandem repeat PCR and the results were in concordance with published data $[57,58]$. All experiments were performed using 5\% FBS in RPMI 1640 media.

\subsection{Reagents and Antibodies}

BRAF inhibitor vemurafenib (PLX4032) and MEK inhibitor selumetinib (AZD6244) were purchased from Selleck Chemicals (Houston, TX, USA). PD-L1 antibody (ab205921) was obtained from Abcam (Cambridge, MA, USA). Antibodies against pMEK1/2 (9121), MEK1/2 (4694), pERK1/2 (4370), ERK1/2 (4695), AKT (9272), Bcl2 (2876), Bcl-XL (2764), cleaved caspase-3 (9661) and PARP (9542) were purchased from Cell Signaling Technology (Danvers, MA, USA). Antibodies against pAKT (sc-7985), caspase-3 (sc-56053) and GAPDH (sc-47724) were purchased from Santa Cruz Biotechnology, Inc. (Santa Cruz, CA, USA).

\subsection{Clonogenic Assay}

The PTC cell lines were seeded at a density of 500 cells per well in a 6-well plate. After attachment, fresh growth medium was added and cells were allowed to grow for 6-8 days. Cell colonies were fixed with formaldehyde ( $4 \%$ ) and stained with crystal violet $(2 \%$ in $10 \%$ methanol). The number of colonies in each well was counted and photographed. 


\subsection{Gene Silencing Using siRNA}

PD-L1 siRNA and scrambled control siRNA were purchased from Ambion (Austin, TX, USA). Cells were transfected using Lipofectamine 2000 (Invitrogen, Carlsbad, CA, USA) for $6 \mathrm{~h}$ following which the lipid and siRNA complex was removed and fresh growth medium was added. After $48 \mathrm{~h}$ of transfection, cells were used for immuno-blotting.

\subsection{Cell Lysis and Immuno-Blotting}

Following treatment, PTC cells were lysed in phosphorylation lysis buffer containing $50 \mathrm{mM}$ HEPES (pH 7.3), $150 \mathrm{mM} \mathrm{NaCl}, 1.5 \mathrm{mM} \mathrm{MgCl}_{2}, 1.0 \mathrm{mM}$ EDTA (pH 8.0), $100 \mathrm{mM} \mathrm{NaF}$, $10 \mathrm{mM} \mathrm{Na}_{2} \mathrm{H}_{2} \mathrm{P}_{2} \mathrm{O}_{7}, 200 \mu \mathrm{M} \mathrm{Na}_{3} \mathrm{VO}_{4}$ and $1 \mathrm{X}$ proteasome inhibitors (Roche pharmaceuticals, Basel, Switzerland). Lysed cells were spun at $14,000 \mathrm{rpm}$ for $15 \mathrm{~min}$ at $4{ }^{\circ} \mathrm{C}$ and protein amounts were measured using a Bradford protein assay kit (Bio-Rad, Hercules, CA, USA). For immuno-blotting, equal amounts of protein $(10 \mu \mathrm{g})$ were subjected to $10 \%$ SDS-PAGE gels, transferred to nitrocellulose membranes, blocked with $5 \%(w / v)$ non-fat dry milk in 1X TBST ( $25 \mathrm{mM}$ Tris-HCl, pH 7.4, $137 \mathrm{mM} \mathrm{NaCl}$, and $0.1 \%$ Tween 20$)$ for $1 \mathrm{~h}$ and incubated with primary antibodies in $2 \%(w / v)$ non-fat dry milk in TBST for $1-2 \mathrm{~h}$. The membranes were washed at least three times with TBST at $10 \mathrm{~min}$ intervals followed by a $1 \mathrm{~h}$ incubation with mouse or rabbit horseradish peroxidase-conjugated secondary antibody (1:5000). The membranes were developed with an enhanced chemiluminescence detection system according to the manufacturer's instructions (ECL, Amersham, IL, USA). All uncropped western blot images are presented in Supplementary Materials Figure S1.

\subsection{Statistical Analysis}

The associations between clinico-pathological variables and protein expression were found using contingency table analysis and chi-square tests. A Mantel-Cox log-rank test was used to evaluate disease-free survival and recurrence-free survival. Survival curves were generated using the Kaplan-Meier method. A Cox proportional hazards regression model was used for multivariate analysis. Two-sided tests were used for statistical analyses with a limit of significance defined as $p$ value $<0.05$. Data analyses were performed using the JMP11.0 (SAS Institute, Inc., Cary, NC, USA) software package.

For all functional studies, data presented are means \pm SD of three independent experiments, which were repeated at least two times with the same results. A Student's $t$-test (two-tailed) was performed for statistical significance with $p<0.05$ used as the cut-off.

\section{Conclusions}

This study suggests that PD-L1 could represent a useful prognostic marker for risk stratification in Middle Eastern PTC and that a PD-1/PD-L1 inhibitor could be a potential therapeutic option for aggressive PTC cancers, such as tall cell variant and BRAF mutationpositive patients that are unresponsive to standard PTC treatment. Furthermore, these data indicate that PTC tumor cells expressing PD-L1 may mediate intrinsic signaling and can affect survival beyond immune regulatory functions, which suggest a broader role for PD-L1 as a potential predictive marker for therapy response.

Supplementary Materials: The following are available online at https:/ /www.mdpi.com/2072-669 4/13/3/555/s1, Figure S1: Uncropped Western Blot Images.

Author Contributions: A.K.S. and S.K.P. designed and wrote the manuscript. S.K.P. prepared the TMA and conducted all the immunohistochemistry experiments and scoring of IHC spots. P.P. and S.P.D. performed experiments and data analysis. S.S.A.-S. and F.A.-D. contributed samples and analyzed clinical data. K.S.A.-K. designed and implemented the study and wrote and critically reviewed the manuscript. All authors have read and agreed to the published version of the manuscript.

Funding: This research received no external funding. 
Institutional Review Board Statement: The study was conducted according to the guidelines of the Declaration of Helsinki, and approved by the Institutional Review Board of King Faisal Specialist Hospital and Research Center (RAC\# 2110031 on 06 February 2012).

Informed Consent Statement: Patient consent was waived since only archival paraffin tissue blocks were used, a waiver of consent was obtained from the Research Advisory Council (RAC) on 06 February 2012 (RAC\# 2110 031).

Data Availability Statement: The data presented in this study are available on request from the corresponding author.

Acknowledgments: We thank Padmanaban Annaiyappanaidu, Roxanne Melosantos, Rafia Begum and Felisa DeVera for their technical assistance.

Conflicts of Interest: The authors declare no conflict of interest.

\section{References}

1. Howlader, N.; Krapcho, M.; Miller, D.; Bishop, K.; Kosary, C.; Yu, M.; Cronin, K.A.; Noone, A.M.; Ruhl, J.; Tatalovich, Z.; et al. (Eds.) SEER Cancer Statistics Review, 1975-2014; National Cancer Institute: Bethesda, MD, USA, 2017.

2. Schneider, D.F.; Chen, H. New developments in the diagnosis and treatment of thyroid cancer. CA Cancer J. Clin. 2013, 63, 373-394. [CrossRef] [PubMed]

3. Xing, M.; Alzahrani, A.S.; Carson, K.A.; Shong, Y.K.; Kim, T.Y.; Viola, D.; Elisei, R.; Bendlová, B.; Yip, L.; Mian, C.; et al. Association between BRAF V600E mutation and recurrence of papillary thyroid cancer. J. Clin. Oncol. 2015, 33, 42. [CrossRef] [PubMed]

4. Ritter, A.; Mizrachi, A.; Bachar, G.; Vainer, I.; Shimon, I.; Hirsch, D.; Diker-Cohen, T.; Duskin-Bitan, H.; Robenshtok, E. Detecting recurrence following lobectomy for thyroid cancer: Role of thyroglobulin and thyroglobulin antibodies. J. Clin. Endocrinol. Metab. 2020, 105, e2145-e2151. [CrossRef] [PubMed]

5. Tumino, D.; Frasca, F.; Newbold, K. Updates on the management of advanced, metastatic, and radioiodine refractory differentiated thyroid cancer. Front. Endocrinol. 2017, 8, 312. [CrossRef] [PubMed]

6. Darvin, P.; Toor, S.M.; Nair, V.S.; Elkord, E. Immune checkpoint inhibitors: Recent progress and potential biomarkers. Exp. Mol. Med. 2018, 50,1-11. [CrossRef]

7. Larkin, J.; Chiarion-Sileni, V.; Gonzalez, R.; Grob, J.J.; Cowey, C.L.; Lao, C.D.; Schadendorf, D.; Dummer, R.; Smylie, M.; Rutkowski, P.; et al. Combined nivolumab and ipilimumab or monotherapy in untreated melanoma. N. Engl. J. Med. 2015, 373, 23-34. [CrossRef]

8. Chen, J.; Jiang, C.; Jin, L.; Zhang, X. Regulation of PD-L1: A novel role of pro-survival signalling in cancer. Ann. Oncol. 2016, 27, 409-416. [CrossRef]

9. Chen, N.; Fang, W.; Zhan, J.; Hong, S.; Tang, Y.; Kang, S.; Zhang, Y.; He, X.; Zhou, T.; Qin, T.; et al. Upregulation of PD-L1 by EGFR activation mediates the immune escape in EGFR-driven NSCLC: Implication for optional immune targeted therapy for NSCLC patients with EGFR mutation. J. Thorac. Oncol. 2015, 10, 910-923. [CrossRef]

10. Zou, W.; Wolchok, J.D.; Chen, L. PD-L1 (B7-H1) and PD-1 pathway blockade for cancer therapy: Mechanisms, response biomarkers, and combinations. Sci. Transl. Med. 2016, 8, rv324-rv328. [CrossRef]

11. Disis, M.L.; Taylor, M.H.; Kelly, K.; Beck, J.T.; Gordon, M.; Moore, K.M.; Patel, M.R.; Chaves, J.; Park, H.; Mita, A.C.; et al. Efficacy and safety of avelumab for patients with recurrent or refractory ovarian cancer: Phase $1 \mathrm{~b}$ results from the JAVELIN solid tumor trial. JAMA Oncol. 2019, 5, 393-401. [CrossRef]

12. Sheng, X.; Yan, X.; Chi, Z.; Si, L.; Cui, C.; Tang, B.; Li, S.; Mao, L.; Lian, B.; Wang, X.; et al. Axitinib in combination with toripalimab, a humanized immunoglobulin G4 monoclonal antibody against programmed cell death-1, in patients with metastatic mucosal melanoma: An open-label phase IB trial. J. Clin. Oncol. 2019, 37, 2987-2999. [CrossRef] [PubMed]

13. Schmid, P.; Adams, S.; Rugo, H.S.; Schneeweiss, A.; Barrios, C.H.; Iwata, H.; Diéras, V.; Hegg, R.; Im, S.-A.; Shaw Wright, G.; et al. Atezolizumab and nab-paclitaxel in advanced triple-negative breast cancer. N. Engl. J. Med. 2018, 379, 2108-2121. [CrossRef] [PubMed]

14. Dang, T.O.; Ogunniyi, A.; Barbee, M.S.; Drilon, A. Pembrolizumab for the treatment of PD-L1 positive advanced or metastatic non-small cell lung cancer. Expert Rev. Anticancer. Ther. 2016, 16, 13-20. [CrossRef] [PubMed]

15. Koemans, W.J.; Chalabi, M.; van Sandick, J.W.; van Dieren, J.M.; Kodach, L.L. Beyond the PD-L1 horizon: In search for a good biomarker to predict success of immunotherapy in gastric and esophageal adenocarcinoma. Cancer Lett. 2019, 442, $279-286$. [CrossRef]

16. Taube, J.M.; Klein, A.; Brahmer, J.R.; Xu, H.; Pan, X.; Kim, J.H.; Chen, L.; Pardoll, D.M.; Topalian, S.L.; Anders, R.A. Association of PD-1, PD-1 ligands, and other features of the tumor immune microenvironment with response to anti-PD-1 therapy. Clin. Cancer Res. 2014, 20, 5064-5074.

17. Doroshow, D.B.; Sanmamed, M.F.; Hastings, K.; Politi, K.; Rimm, D.L.; Chen, L.; Melero, I.; Schalper, K.A.; Herbst, R.S. Immunotherapy in non-small cell lung cancer: Facts and hopes. Clin. Cancer Res. 2019, 25, 4592-4602. [CrossRef] 
18. Mehnert, J.M.; Varga, A.; Brose, M.S.; Aggarwal, R.R.; Lin, C.-C.; Prawira, A.; De Braud, F.; Tamura, K.; Doi, T.; Piha-Paul, S.A.; et al. Safety and antitumor activity of the anti-PD-1 antibody pembrolizumab in patients with advanced, PD-L1-positive papillary or follicular thyroid cancer. BMC Cancer 2019, 19, 196. [CrossRef]

19. Azuma, T.; Yao, S.; Zhu, G.; Flies, A.S.; Flies, S.J.; Chen, L. B7-H1 is a ubiquitous antiapoptotic receptor on cancer cells. Blood J. Am. Soc. Hematol. 2008, 111, 3635-3643. [CrossRef]

20. Clark, C.A.; Gupta, H.B.; Sareddy, G.; Pandeswara, S.; Lao, S.; Yuan, B.; Drerup, J.M.; Padron, A.; Conejo-Garcia, J.; Murthy, K.; et al. Tumor-intrinsic PD-L1 signals regulate cell growth, pathogenesis, and autophagy in ovarian cancer and melanoma. Cancer Res. 2016, 76, 6964-6974. [CrossRef]

21. Lastwika, K.J.; Wilson, W.; Li, Q.K.; Norris, J.; Xu, H.; Ghazarian, S.R.; Kitagawa, H.; Kawabata, S.; Taube, J.M.; Yao, S.; et al. Control of PD-L1 expression by oncogenic activation of the AKT-mTOR pathway in non-small cell lung cancer. Cancer Res. 2016, 76, 227-238. [CrossRef]

22. Kleffel, S.; Posch, C.; Barthel, S.R.; Mueller, H.; Schlapbach, C.; Guenova, E.; Elco, C.P.; Lee, N.; Juneja, V.R.; Zhan, Q.; et al. Melanoma cell-intrinsic PD-1 receptor functions promote tumor growth. Cell 2015, 162, 1242-1256. [CrossRef] [PubMed]

23. Orzechowski, A.; Dong, H. B7-H1 confers tumor chemoresistance by regulating MAPK/ERK activation. In Proceedings of the AACR Annual Meeting, San Diego, CA, USA, 5-9 April 2014.

24. Mohanty, A.; Afkhami, M.; Pharaon, R.; Yin, H.; Sun, J.; Nam, A.; Chang, S.; Gernon, T.; Kang, R.; Amini, A.; et al. Inhibition of BRAF induces PD-L1 expression in BRAF-mutated papillary thyroid carcinoma. Int. J. Radiat. Oncol. Biol. Phys. 2020, 106, 1192-1193. [CrossRef]

25. Zaballos, M.A.; Santisteban, P. Key signaling pathways in thyroid cancer. J. Endocrinol. 2017, 235, R43-R61. [CrossRef] [PubMed]

26. Gan, X.; Shen, F.; Deng, X.; Feng, J.; Lu, J.; Cai, W.; Peng, L.; Zheng, W.; Wang, W.; Huang, P.; et al. Prognostic implications of the BRAF-V600E mutation in papillary thyroid carcinoma based on a new cut-off age stratification. Oncol. Lett. 2020, 19, 631-640. [CrossRef] [PubMed]

27. Katano, T.; Oda, T.; Sekine, A.; Sato, M.; Yamaya, T.; Sato, Y.; Okudela, K.; Hagiwara, E.; Ogura, T. Five cases of BRAF V600Emutant lung adenocarcinoma with high expression of programmed death ligand 1. Respir. Med. Case Rep. 2020, $30,101071$. [CrossRef] [PubMed]

28. Dudnik, E.; Peled, N.; Nechushtan, H.; Wollner, M.; Onn, A.; Agbarya, A.; Moskovitz, M.; Keren, S.; Popovits-Hadari, N.; Urban, D.; et al. BRAF mutant lung cancer: Programmed death ligand 1 expression, tumor mutational burden, microsatellite instability status, and response to immune check-point inhibitors. J. Thorac. Oncol. 2018, 13, 1128-1137. [CrossRef] [PubMed]

29. Angell, T.E.; Lechner, M.G.; Jang, J.K.; Correa, A.J.; LoPresti, J.S.; Epstein, A.L. BRAFV600E in papillary thyroid carcinoma is associated with increased programmed death ligand 1 expression and suppressive immune cell infiltration. Thyroid 2014, 24, 1385-1393. [CrossRef]

30. Feng, D.; Qin, B.; Pal, K.; Sun, L.; Dutta, S.; Dong, H.; Liu, X.; Mukhopadhyay, D.; Huang, S.; Sinicrope, F.A. BRAF V600E-induced, tumor intrinsic PD-L1 can regulate chemotherapy-induced apoptosis in human colon cancer cells and in tumor xenografts. Oncogene 2019, 38, 6752-6766.

31. Shi, R.-1.; Qu, N.; Luo, T.-X.; Xiang, J.; Liao, T.; Sun, G.-h.; Wang, Y.; Wang, Y.-1.; Huang, C.-p.; Ji, Q.-h. Programmed death-ligand 1 expression in papillary thyroid cancer and its correlation with clinicopathologic factors and recurrence. Thyroid 2017, 27, 537-545. [CrossRef]

32. Ahn, S.; Kim, T.H.; Kim, S.W.; Ki, C.S.; Jang, H.W.; Kim, J.S.; Kim, J.H.; Choe, J.-H.; Shin, J.H.; Hahn, S.Y.; et al. Comprehensive screening for PD-L1 expression in thyroid cancer. Endocr. Relat. Cancer 2017, 24, 97-106. [CrossRef]

33. Chowdhury, S.; Veyhl, J.; Jessa, F.; Polyakova, O.; Alenzi, A.; MacMillan, C.; Ralhan, R.; Walfish, P.G. Programmed death-ligand 1 overexpression is a prognostic marker for aggressive papillary thyroid cancer and its variants. Oncotarget 2016, 7, 32318. [CrossRef] [PubMed]

34. Lim, H.; Devesa, S.S.; Sosa, J.A.; Check, D.; Kitahara, C.M. Trends in thyroid cancer incidence and mortality in the United States, 1974-2013. JAMA 2017, 317, 1338-1348. [CrossRef] [PubMed]

35. Xing, M.; Alzahrani, A.S.; Carson, K.A.; Viola, D.; Elisei, R.; Bendlova, B.; Yip, L.; Mian, C.; Vianello, F.; Tuttle, R.M.; et al. Association between BRAF V600E mutation and mortality in patients with papillary thyroid cancer. JAMA 2013, 309, $1493-1501$. [CrossRef] [PubMed]

36. Howlader, N.; Noone, A.; Krapcho, M.; Garshell, J.; Miller, D.; Altekruse, S.; Kosary, C.; Yu, M.; Ruhl, J.; Tatalovich, Z.; et al. (Eds.) SEER Cancer Statistics Review, 1975-2012; National Cancer Institute: Bethesda, MD, USA, 2015.

37. Fallahi, P.; Mazzi, V.; Vita, R.; Ferrari, S.M.; Materazzi, G.; Galleri, D.; Benvenga, S.; Miccoli, P.; Antonelli, A. New therapies for dedifferentiated papillary thyroid cancer. Int. J. Mol. Sci. 2015, 16, 6153-6182. [CrossRef]

38. Fugazzola, L.; Elisei, R.; Fuhrer, D.; Jarzab, B.; Leboulleux, S.; Newbold, K.; Smit, J. 2019 European Thyroid Association Guidelines for the Treatment and Follow-Up of Advanced Radioiodine-Refractory Thyroid Cancer. Eur. Thyroid. J. 2019, 8, $227-245$. [CrossRef]

39. Yi, M.; Jiao, D.; Xu, H.; Liu, Q.; Zhao, W.; Han, X.; Wu, K. Biomarkers for predicting efficacy of PD-1/PD-L1 inhibitors. Mol. Cancer 2018, 17, 1-14. [CrossRef]

40. Davis, A.A.; Patel, V.G. The role of PD-L1 expression as a predictive biomarker: An analysis of all US Food and Drug Administration (FDA) approvals of immune checkpoint inhibitors. J. Immunother. Cancer 2019, 7, 278. [CrossRef] 
41. Li, Y.; Liang, L.; Dai, W.; Cai, G.; Xu, Y.; Li, X.; Li, Q.; Cai, S. Prognostic impact of programed cell death-1 (PD-1) and PD-ligand 1 (PD-L1) expression in cancer cells and tumor infiltrating lymphocytes in colorectal cancer. Mol. Cancer 2016, 15, 55. [CrossRef]

42. Qin, T.; Zeng, Y.-D.; Qin, G.; Xu, F.; Lu, J.-B.; Fang, W.-F.; Xue, C.; Zhan, J.-H.; Zhang, X.-K.; Zheng, Q.-F.; et al. High PD-L1 expression was associated with poor prognosis in 870 Chinese patients with breast cancer. Oncotarget 2015, 6, 33972. [CrossRef]

43. Wang, Q.; Lou, W.; Di, W.; Wu, X. Prognostic value of tumor PD-L1 expression combined with CD8+ tumor infiltrating lymphocytes in high grade serous ovarian cancer. Int. Immunopharmacol. 2017, 52, 7-14. [CrossRef]

44. Pawelczyk, K.; Piotrowska, A.; Ciesielska, U.; Jablonska, K.; Glatzel-Plucinska, N.; Grzegrzolka, J.; Podhorska-Okolow, M.; Dziegiel, P.; Nowinska, K. Role of PD-L1 expression in non-small cell lung cancer and their prognostic significance according to clinicopathological factors and diagnostic markers. Int. J. Mol. Sci. 2019, 20, 824. [CrossRef] [PubMed]

45. Aghajani, M.J.; Yang, T.; McCafferty, C.E.; Graham, S.; Wu, X.; Niles, N. Predictive relevance of programmed cell death protein 1 and tumor-infiltrating lymphocyte expression in papillary thyroid cancer. Surgery 2018, 163, 130-136. [CrossRef] [PubMed]

46. Sumimoto, H.; Takano, A.; Teramoto, K.; Daigo, Y. RAS-mitogen-activated protein kinase signal is required for enhanced PD-L1 expression in human lung cancers. PLOS ONE 2016, 11, e0166626. [CrossRef]

47. Della Corte, C.M.; Barra, G.; Ciaramella, V.; Di Liello, R.; Vicidomini, G.; Zappavigna, S.; Luce, A.; Abate, M.; Fiorelli, A.; Caraglia, M.; et al. Antitumor activity of dual blockade of PD-L1 and MEK in NSCLC patients derived three-dimensional spheroid cultures. J. Exp. Clin. Cancer Res. 2019, 38, 253. [CrossRef] [PubMed]

48. Stutvoet, T.S.; Kol, A.; de Vries, E.G.; de Bruyn, M.; Fehrmann, R.S.; Terwisscha van Scheltinga, A.G.; de Jong, S. MAPK pathway activity plays a key role in PD-L1 expression of lung adenocarcinoma cells. J. Pathol. 2019, 249, 52-64. [CrossRef]

49. Ghebeh, H.; Lehe, C.; Barhoush, E.; Al-Romaih, K.; Tulbah, A.; Al-Alwan, M.; Hendrayani, S.-F.; Manogaran, P.; Alaiya, A.; Al-Tweigeri, T.; et al. Doxorubicin downregulates cell surface B7-H1 expression and upregulates its nuclear expression in breast cancer cells: Role of B7-H1 as an anti-apoptotic molecule. Breast Cancer Res. 2010, 12, R48. [CrossRef]

50. Liu, J.; Quan, L.; Zhang, C.; Liu, A.; Tong, D.; Wang, J. Over-activated PD-1/PD-L1 axis facilitates the chemoresistance of diffuse large B-cell lymphoma cells to the CHOP regimen. Oncol. Lett. 2018, 15, 3321-3328. [CrossRef]

51. Yan, F.; Pang, J.; Peng, Y.; Molina, J.R.; Yang, P.; Liu, S. Elevated cellular PD1/PD-L1 expression confers acquired resistance to cisplatin in small cell lung cancer cells. PLoS ONE 2016, 11, e0162925. [CrossRef]

52. Abubaker, J.; Jehan, Z.; Bavi, P.; Sultana, M.; Al-Harbi, S.; Ibrahim, M.; Al-Nuaim, A.; Ahmed, M.; Amin, T.; Al-Fehaily, M.; et al. Clinicopathological analysis of papillary thyroid cancer with PIK3CA alterations in a Middle Eastern population. J. Clin. Endocrinol. Metab. 2008, 93, 611-618. [CrossRef]

53. Bu, R.; Siraj, A.K.; Al-Obaisi, K.A.; Beg, S.; Al Hazmi, M.; Ajarim, D.; Tulbah, A.; Al-Dayel, F.; Al-Kuraya, K.S. Identification of novel BRCA founder mutations in Middle Eastern breast cancer patients using capture and Sanger sequencing analysis. Int. J. Cancer 2016, 139, 1091-1097. [CrossRef]

54. Siraj, A.; Bavi, P.; Abubaker, J.; Jehan, Z.; Sultana, M.; Al-Dayel, F.; Al-Nuaim, A.; Alzahrani, A.; Ahmed, M.; Al-Sanea, O.; et al. Genome-wide expression analysis of Middle Eastern papillary thyroid cancer reveals c-MET as a novel target for cancer therapy. J. Pathol. 2007, 213, 190-199. [CrossRef] [PubMed]

55. Bavi, P.; Jehan, Z.; Atizado, V.; Al-Dossari, H.; Al-Dayel, F.; Tulbah, A.; Amr, S.S.; Sheikh, S.S.; Ezzat, A.; El-Solh, H.; et al. Prevalence of fragile histidine triad expression in tumors from Saudi Arabia: A tissue microarray analysis. Cancer Epidemiol. Prev. Biomark. 2006, 15, 1708-1718. [CrossRef] [PubMed]

56. Mesnage, S.; Auguste, A.; Genestie, C.; Dunant, A.; Pain, E.; Drusch, F.; Gouy, S.; Morice, P.; Bentivegna, E.; Lhomme, C.; et al. Neoadjuvant chemotherapy (NACT) increases immune infiltration and programmed death-ligand 1 (PD-L1) expression in epithelial ovarian cancer (EOC). Ann. Oncol. 2017, 28, 651-657. [CrossRef] [PubMed]

57. Zhao, M.; Sano, D.; Pickering, C.R.; Jasser, S.A.; Henderson, Y.C.; Clayman, G.L.; Sturgis, E.M.; Ow, T.J.; Lotan, R.; Carey, T.E.; et al. Assembly and initial characterization of a panel of 85 genomically validated cell lines from diverse head and neck tumor sites. Clin. Cancer Res. 2011, 17, 7248-7264. [CrossRef] [PubMed]

58. Bu, R.; Siraj, A.K.; Divya, S.P.; Kong, Y.; Parvathareddy, S.K.; Al-Rasheed, M.; Al-Obaisi, K.A.; Victoria, I.G.; Al-Sobhi, S.S.; Al-Dawish, M.; et al. Telomerase reverse transcriptase mutations are independent predictor of disease-free survival in Middle Eastern papillary thyroid cancer. Int. J. Cancer 2018, 142, 2028-2039. [CrossRef] 